\section{DANDELION}

postgraduate arts journal \& research network

VOLUME 5 NUMBER I SUMMER 2014
Dr AdAM Brown is a Lecturer in Media Studies at Deakin University, Australia, and works as a volunteer at the Jewish Holocaust Centre in Melbourne. He is the author of Judging 'Privileged' Jews: Holocaust Ethics, Representation and the 'Grey Zone' (Berghahn, 2013) and co-author of Communication, New Media and Everyday Life (Oxford UP, 2012). Intensely interested in animal and human rights issues, Adam's interdisciplinary research has spanned Holocaust representation across various genres, surveillance and film, mediations of rape, digital children's television, and board game culture.

http://adamgbrown.wordpress.com/

Dr Deb Waterhouse-WAtson is an Associate Lecturer in Media and Communication Studies at Monash University, Australia. The author of Athletes, Sexual Assault and 'Trials by Media: Narrative Immunity (Routledge, 2013), Deb's research interests include gender and representation in Holocaust film, the news media, and other popular cultural texts, board game culture, and representations of sexual violence.

https://monash.academia.edu/DebWaterhouseWatson

Article

\title{
The Other Side of a Slap in the Face: Judgement and the Ambiguities of Violence in Holocaust Testimony
}

Dr Adam Brown and Dr Deb Waterhouse-Watson

At the first blow [...] trust in the world breaks down. The other person, opposite whom I exist physically in the world and with whom I can exist only as long as he [sic] does not touch my skin surface as border, forces his own corporeality on me with the first blow. He is on me and thereby destroys me.'

THE PASSAGE ABOVE, TAKEN FROM THE INFLUENTIAL PHILOSOPHICAL TESTIMONY OF JEAN AmÉry, reflects on the author's wartime torture at the hands of the Gestapo - an experience that, at least in part (in addition to his later imprisonment in Auschwitz), led to his suicide in 1978. Nazi violence, its motivations, and effects have preoccupied historians, philosophers, and psychologists for decades. This paper focuses on the related though considerably different issue of the violence of victims toward other victims which resulted from the Nazis' extensive use of racialised prisoner hierarchies in the concentration camps, as well as employment of 'privileged' positions that further encouraged antagonism, if not physical violence. This complex and sensitive issue has remained largely taboo, though it is fundamental to 
deepening understandings of the Holocaust and what it revealed about human behaviour in extremis.

Numerous Holocaust testimonies describe incidents when prisoners around them were beaten and sometimes killed by functionaries appointed by the Nazi German perpetrators in concentration camps and ghettos. Inevitably and understandably - such accounts generally condemn this behaviour, passing strong moral judgements on victims who (to use the most frequently adopted term) 'collaborated' with the enemy. Indeed, distinctions between 'privileged' prisoners and perpetrators of genocide are not always clear, but are oftentimes blurred, with many prisoners rarely seeing SS officers but constantly coming face-to-face with prisoner Kapos ('chiefs') of forced labour squads or the Ordnungsdienst ('Order Service', or Jewish police) patrolling the streets of the ghettos. As a result, the vexed themes of moral ambiguity and 'compromise' permeate the Holocaust, with significant and ethically fraught implications for representation and judgement. This problem is spelt out in Auschwitz survivor Primo Levi's paradigmatic essay on the 'grey zone', in which he argues that moral evaluations of victims who were forced to cooperate with their persecutors should be suspended. Taking Levi's 'grey zone' as a point of departure, this paper responds to a gap in the critical literature by closely analysing Holocaust testimonies written by (former) 'privileged' Jews themselves: Calel Perechodnik's Am I a Murderer?: Testament of a Jewish Ghetto Policeman (1993) and Paul Steinberg's Speak You Also: A Survivor's Reckoning (1996). ${ }^{2}$ Positioning the problems of judgement and representation as pivotal to ethically engaging with victim behaviour in extremis, we reveal that considerable light can be shed on the complexity of Holocaust violence by exploring texts that engage with these issues.

\section{Negotiating the 'Grey Zone': The Abused, the Abuser, and the Ethics of (Engaging with) Holocaust Testimony}

During his time in Auschwitz between 22 February 1944 and 27 January 1945, Primo Levi was exposed to harsh and dehumanising conditions, enduring manual labour for many months before obtaining a specialist position in a chemical laboratory that helped, along with several other factors (not least of all, chance), save his life. He took mental notes of everything he could, preserving detailed memories of the minutiae of camp life that would form the backbone of his memoirs. ${ }^{3}$ While he felt that his writing helped him to come to terms with his traumatic wartime experiences to some degree, one issue in particular seems to have perturbed him for decades. In a 1975 foreword to his translation of Jacques Presser's Dutch novel, The Night of the Girondists, focusing on a young Dutch Jew who helps the Nazis deport fellow Jews to Auschwitz, Levi wrote:

There are enough signs to indicate that the time has come to explore the space that divides the victims from their executioners, and to go about it with considerably more delicacy and clearsightedness than has been evident, for instance, in certain well-known recent films. It would take a Manichean to argue that such a space is empty. Empty it is not: it is studded with sordid, deplorable or pathetic creatures (occasionally the three at once). ${ }^{4}$

This provides an early formulation of Levi's 'grey zone', and highlights several pertinent points that became even more crucial to his later writings.

The provocative delineation of a 'space' situated between the categories 
of persecuted and persecutors underlines the sensitive nature of the task Levi took upon himself, and he was often accused of unethically blurring these categories. Prominent survivor Elie Wiesel, who was for a time in the same camp barracks as Levi, strongly criticised him for 'attenuating the guilt of the killers': 'I thought [Levi] too severe with survivors. There our disagreement was total, he ascribed too much guilt to them. ${ }^{, 5}$ Yet we argue that this criticism derives from a misreading of Levi's essay, which stresses at frequent intervals the necessity of maintaining the fundamental distinction between victim and perpetrator. ${ }^{6}$ Indeed, in 'The Grey Zone' Levi is preoccupied with the inappropriateness of judging 'privileged' Jews. Regarding both his essay's major case studies - the Sonderkommandos ('special squads') forced to work in the gas chambers and crematoria of Auschwitz, and Mordechai Chaim Rumkowski, the controversial Judenrat (Jewish council) leader of the Lodz Ghetto - Levi argues that one must suspend judgement of their activities. Yet if judgement of liminal figures is inevitable, as well as 'impossible', it is because the nature of language itself guarantees this. Even a seemingly simple statement, such as claiming that a 'privileged' prisoner 'committed a violent act', sounds like a legal pronouncement and therefore evokes criminal connotations. The connotations of 'privileged' itself must be qualified by inverted commas. This raises crucial questions: if 'privileged' Jews are not to be judged for their behaviour in situations beyond their control, how can/should their experiences be represented? And when these experiences include violent acts against fellow victims, how can distinctions between groups of victims - those with 'privileged' positions and those without - be drawn without undermining the crucial separation of victims from persecutors?

The category of 'privileged' Jews includes those prisoners in the Nazicontrolled camps and ghettos who held positions that gave them access to material and other benefits beyond those available to other Jews. ${ }^{7}$ These figures were under extreme levels of coercion, compelled to act in ways some have judged to be both self-serving and harmful to fellow inmates. Important to note is that 'privilege' could only prolong their lives temporarily - all Jews were intended to die in the Holocaust. Nevertheless, maintaining one's lifeprolonging 'privileged' position often involved a perceived or actual need (or, as some survivors note, opportunity) to engage in violence against other prisoners. Such behaviour, influenced by unprecedented Nazi persecution and potentially diminishing the chances of other victims' survival, can neither be demonised as barbaric nor glorified as heroic. As Levi implies in the passage quoted above and as he explicitly states in his later essay on the 'grey zone' - 'privileged' Jews' circumstances cannot be understood via the widespread Manichean tendency towards simplistic binary oppositions of 'good' and 'evil', 'friend' and 'enemy', shunning the 'half-tints and complexities' - the greyness - of human behaviour. ${ }^{8}$ Levi viewed this tendency as particularly relevant to representations of the Holocaust in fiction films, although recent research highlights that similar judgements can be found across video testimonies, historical writing, and documentaries. ${ }^{9}$ The negotiation of this issue in the immense and diverse range of survivors' written accounts, however, has on the whole been neglected.

Toward the end of 'The Grey Zone,' Levi raises a crucial point that cannot be easily set aside: like most 'privileged' Jews, the only words about Rumkowski that we lack and can never obtain are his own. Levi writes that only Rumkowski could clarify his situation 'if he could speak before us, even lying, as perhaps he always lied, to himself also; he would in any case help us understand him, as every defendant helps his judge. ${ }^{10}$ The same problem is apparent in the 
case of the Sonderkommandos, whom Levi also highlighted as centrally located in the 'grey zone.' Very few of these traumatised men survived the Holocaust and fewer still have spoken of their experiences or written memoirs. A small number of survivors have told how, under threat - and reality - of imminent death (each 'special squad' was killed after several weeks), the crematorium workers were forced to deceive and guide other victims toward the gas, sort their belongings, and later clean the chambers and burn the bodies. While these men gained access to several material benefits for their cooperation, Levi notes that 'here one hesitates to speak of privilege.' ${ }^{11}$ While it should be acknowledged that even in the charnel houses of the death camps, some gestures of resistance were possible - several photographs were taken of an outdoor pyre used to cremate bodies and an armed revolt destroyed a crematorium on 7 October 1944 - the desperate situation of the Sonderkommandos cannot be stressed enough. Filip Müller, a Slovakian Jew incarcerated in Auschwitz from April 1942 to November 1944 and a survivor of the Sonderkommandos, sums this up in his memoir: 'Any refusal to work, even the merest hint, would have meant certain death without the slightest effect on the course of events. ${ }^{, 12}$ Faced with the problem of how to understand such extreme circumstances, it has been the ongoing task of the scholar to piece together the debris of the past to approach a better understanding of it. Judgement plays a crucial role in this. By explicitly and self-reflexively engaging with this complex issue, Levi invokes the need to suspend judgement when representing 'privileged' Jews, yet (mostly negative) evaluations of their behaviour are evident across countless texts.

Returning to Améry's personal reflections in At the Mind's Limits: Contemplations by a Survivor on Auschwitz and Its Realities (1980), at one point his focus on Nazi violence turns briefly to violence directed at him by a 'privileged' prisoner-functionary in Buna-Monowitz (the same part of Auschwitz where Levi and Wiesel were incarcerated). In the context of the need to re-assert one's dignity through resistance, Améry writes:

Before me I see the prisoner foreman Juszek, a Polish professional criminal of horrifying vigor. In Auschwitz he once hit me in the face because of a trifle; that is how he was used to dealing with all the Jews under his command. At this moment - I felt it with piercing clarity - it was up to me to go a step further in my prolonged appeals case against society. In open revolt I struck Juszek in the face in turn. My human dignity lay in this punch to his jaw - and that it was in the end I, the physically much weaker man, who succumbed and was woefully thrashed, meant nothing to me. Painfully beaten, I was satisfied with myself. $^{13}$

Of course, Améry is in no way obligated to explore the situation from his abuser's perspective - suggesting otherwise would be perverse - however, the picture the survivor evokes cannot be filled out in its entirety without considering how one might perceive and position the 'privileged' prisoner. That Juszek's act can be described as 'violent' is undeniable, as is the fact that Améry's use of violence to re-assert himself 'in the world' is a different kind of violence from Juszek's. Nevertheless, important questions remain: what role and culpability in Juszek's behaviour can be allocated to the Nazi perpetrator's establishment of the 'divide and conquer' camp system? How is Juszek's situation to be considered, given that 'privileged' positions were not necessarily permanent and often depended on keeping 'order' among the prisoners they were held responsible for, through the threat of severe punishment? Are there extenuating factors, and should these be considered? How does one 
differentiate and hold in balance the perspectives of the abused and the abuser without trivialising such trauma and violence and, as a result, banalising the horrific settings of the camps and ghettos? Such questions are not raised to trivialise Améry's suffering or expression of reignited dignity, nor are they to blindly excuse Juszek's behaviour (certainly survivors remember camp prisoners incarcerated for past criminal activities least sympathetically), but these questions pose additional dilemmas to Améry's meditation on his confrontation with his 'opponent'. ${ }^{\text {' }}$

'Privileged' prisoners acted in various ways, for various reasons and under varying levels of coercion. With agency and thus accountability difficult - if not impossible - to evaluate, at such a distance of time and experience (and arguably even without this), it is problematic for anyone to evaluate the consequences, motivations and personal autonomy that were in play during the Holocaust. Questions of judgement and representation in relation to the violence inflicted by 'privileged' prisoners on other prisoners are perhaps even more vexed when the 'privileged' prisoners are Jewish - thus occupying the lowest and most vulnerable rung of the imposed camp hierarchy (and hence more at risk of losing such positions). Yet negative judgements regarding the cooperation of 'privileged' Jews are common. For example, Chaim Rumkowski (mentioned above) - arguably the most despised Jewish leader in Holocaust testimony - makes frequent, and generally unsympathetic, appearances in Abraham Biderman's The World of my Past (1995) and Jacob Rosenberg's East of Time (2005), although both authors incorporate brief reflections on the impossible situation he faced and the difficulty in judging him. ${ }^{15}$ Lucille Eichengreen, on the other hand, dedicates her memoir Rumkowski and the Orphans of Lodz (2000) to condemning Rumkowski as a tyrant who abused his power at every turn. ${ }^{16}$

While a vast and ever-growing literature explores the genre of Holocaust testimony, ${ }^{17}$ this issue has received little attention in relation to 'privileged' Jews, particularly in relation to firsthand accounts by 'privileged' Jews themselves. These testimonies include Miklos Nyiszli's memoir about his experiences performing autopsies for Josef Mengele's pseudo-scientific experiments in Auschwitz-Birkenau; Gisella Perl's account of her time as a prisoner-doctor in the same camp, performing covert abortions to save prisoners from the gas chambers while working with Mengele; and Jewish leader Adam Czerniakow's painstakingly-compiled diary entries of his daily struggles to manage the operation of the Warsaw Ghetto. ${ }^{18}$ Perhaps unsurprisingly, such accounts are rare, due to either very low survival rate among even 'privileged' prisoners or their reticence at telling their stories for fear of self-incrimination or even revenge. Yet these accounts provide unparalleled insights into the extreme double binds they encountered and how they dealt with being situated (or 'trapped', if this is not too positive a judgement) between the Nazi guards and bureaucrats 'above' them and the Jewish prisoners 'below' them. Exemplifying what Lawrence Langer has termed 'choiceless choices' (a concept frequently connected with Levi's 'grey zone'), ${ }^{19}$ the memoir of Ella Lingens-Reiner, a German political inmate and prisonerdoctor, reflects on the dilemma she faced in trying to use her 'privileged' position in the Auschwitz women's camp to help others amidst the Nazis' obsession with numbers: 'If I rescued one woman, I pushed another to her doom, another who wanted to live and had an equal right to live ... Was there any sense in trying to behave decently? ${ }^{20}$ This example points to the fraught nature of classifying victim behaviour under Nazi persecution: is an attempted 'rescue' like Lingens-Reiner describes a heroic act? Does it involve a form of 
indirect violence to the prisoner who is chosen for the gas chambers instead? And what exactly does violence mean in an unprecedented situation like this?

Notably, Levi himself emphasises on numerous occasions the ambiguous nature of violence between prisoners of different 'rank'. He writes that due to language barriers among prisoners of distinct nationalities, Kapo beatings were often ambiguous, as they could be interpreted as an almost 'friendly' incitement to work, a warning, punishment or as completely senseless. ${ }^{21}$ In a short story, 'The Juggler', Levi reflects at length on being 'slammed to the ground with a violent slap' by Eddy, a criminal prisoner and Kapo's assistant, when he is caught writing a letter in the Buna-Monowitz (Auschwitz III) labour camp. ${ }^{22}$ Rather than be offended, Levi reads Eddy's strike as life-saving friendliness akin to a 'friendly smack you give a dog', given that Eddy did not turn him in to the SS for an almost certain death sentence. Levi writes:

\section{A slap inflicted in the Camp had a very different significance from what it might have here among us in today's here and now. Precisely: it had a meaning; it was simply another way of expressing oneself. [...] punches and slaps passed among us as daily language, and we soon learned to distinguish meaningful blows from the others inflicted out of savagery, to create pain and humiliation, and which often result in death. ${ }^{23}$}

While there were undoubtedly less ambiguous forms of violence, this underlines the difficulty prisoners might themselves have had - much less contemporary readers of their testimonies - in interpreting 'privileged' prisoners' behaviour.

While we principally focus here on violence as the (more conventionally conceived) rendering of an injurious act by one person onto another, the concept of 'violence' in relation to the issue of 'privileged' Jews takes on a multiplicity of guises. In addition to (physical) violence against the body, emotional or psychological violence can be done through threats and trauma experienced in a dehumanising setting such as a concentration camp and ghetto. Further, in a more rhetorical sense, 'violence' can be inflicted through representation. The ambiguities of violence in relation to 'privileged' Jews can encompass all of these forms, as our analysis of major case studies illustrates. Indeed, these forms are closely interconnected, for a physical act of violence toward another can (and, in this context, frequently did) translate into trauma for the abuser as well as the abused. Any attempt to depict such an exchange particularly between victims in the extreme, Nazi-created and controlled circumstances of the Holocaust (which can never be fully captured in its 'unrepresentability') does a degree of 'violence' to both: the experiences of abused and abuser must be simplified through language to be understood, with judgement playing a fundamental role in this process. Indeed, Levi himself demonstrated his awareness of this in a 1975 interview, when he declared: 'a human being is a "unique," complicated object. When that object is reduced to a page, even by the best writers, it's reduced to a skeleton'. ${ }^{24}$ Thus the issue(s) of violence regarding 'privileged' Jews must be approached - like the Holocaust in general - with due care.

In the following sections, we analyse various ways in which 'privileged' Jews recount particular acts of violence - sometimes their colleagues', sometimes their own - and consider the implications for engaging with their testimonies. Most violence in such accounts is, of course, committed by Nazi perpetrators and collaborators, who also bear moral responsibility for their victims' behaviour, though limitations of space do not allow for a detailed comparison here. Fluctuating between lamentations and attempts to 
rehabilitate themselves, testimonies of former 'privileged' prisoners encompass self-justifications, self-accusations - even self-hatred - disrupting conventional modes of identification and complicating the reading process. This signals the centrally important, though difficult to articulate, ethics of reading Holocaust testimony. As Dominick LaCapra emphasises in his chapter, 'Holocaust Testimonies: Attending to the Victim's Voice', a key issue to reflect on in relation to testimony is how to 'come to terms with affect in those who have been victimized and traumatized by their experiences, a problem that involves the tense relation between procedures of objective reconstruction of the past and empathic response, especially in the case of victims and survivors'. ${ }^{25}$ This tension is particularly acute when confronting the behaviour of 'privileged' prisoners, which (following Levi) must not be condemned or condoned. Yet readers must also respect the trauma 'privileged' Jews themselves endured trauma invariably spelt out in detail throughout their testimonies.

Robert Rozett writes that Jewish witnesses' firsthand accounts cannot clarify the Nazis' motives or plans, but 'can only teach us about the effect of the horror on the individual victims and the experiences of the victims facing the horror. ${ }^{26}$ This acknowledgement of perspective does not detract from the crucial importance of survivor accounts; however, an awareness of the subjective nature of diaries, memoirs, and oral testimonies raises important ethical questions when considering how survivors represent their own or others' experiences. In investigating this issue, we take a 'metaethical' approach. John K. Roth defines 'metaethics' as a reflection on judgements that have already been made, which 'seek[s] to understand more fully how those judgments work as well as what limits they face and problems they entail'. ${ }^{27}$ In this manner, the problem of judgement, the ambiguities of violence, and the complexities of the often violent relationship between 'abused' and 'abuser' in Levi's 'grey zone' become most apparent. We turn first to the posthumously published diary of Calel Perechodnik, a member of the Otwock Ghetto's Jewish police.

\section{'I don't ask to be absolved': Calel Perechodnik}

Jews became members of the Ordnungsdienst by volunteering, having advantageous contacts, or being randomly conscripted by Nazi authorities. Armed with truncheons and sometimes whips, Jewish police were charged with keeping order in the ghettos; enforcing Nazi regulations; guarding fences and Judenrat institutions; collecting property confiscated by the SS; and, most controversially, escorting fellow Jews, sometimes through violent means, to the trains bound for extermination camps. ${ }^{28}$ Further exemplifying the 'choiceless choices' at the centre of Levi's 'grey zone', Jewish police often had to arrest a daily 'quota' of people for deportation lest they and their families suffer the same fate. Armed Germans or collaborators always supervised their activities to ensure that they behaved as expected and with the required violence. Being in the Ordnungsdienst had the potential to prolong life through extra food, freedom of movement, exemptions from searches and evictions, and (initially) immunity from deportation; however, it is crucial to remember that the ghettos were only established as a temporary measure. Ultimately, most Jewish police like the majority of other 'privileged' Jews - did not survive the Holocaust.

For perhaps predictable reasons, members of the Jewish police who did survive rarely left firsthand accounts, therefore the manuscript of Calel Perchodnik is a highly significant primary source text. ${ }^{29}$ The sensitive nature of its subject matter is evidenced in the fact that publication was delayed until 
1993, at least in part because it eschews 'the comforting rhetoric of heroism'. ${ }^{30}$ Indeed, the narrative's focus on what has often been interpreted as 'Jewish complicity' in their own persecution is reinforced through Perechodnik's own condemnation of Jewish leaders and institutions. The author's own activities drew immediate criticism from the reading public, including the manuscript's Polish editor, who labelled Perechodnik a 'collaborator'. ${ }^{31}$ Drawing on Levi's 'grey zone', Frank Fox counters these judgements in the text's English translation: 'To say that Perechodnik was a collaborator in extermination, a tormentor, or a perpetrator is a judgment we should hesitate to make. Most of the Jewish policemen were eventually killed, though not because of their deeds. They were killed because they were Jews'. ${ }^{32}$ Fox's self-reflexive foreword provides important context for reading the manuscript; nonetheless, some of the sentiments Perechodnik expresses will inevitably unsettle its audience from his disgust at Jewish responses to his virulent desire for revenge. ${ }^{33}$

In 1941, in order to avoid the roundups for labour camps, Perechodnik then 27 years old - became a member of the ghetto police in Otwock, near Warsaw, capital of then Nazi-occupied Poland. He survived the Ghetto's liquidation to escape and join the Polish underground, but soon developed typhus and was discharged. Dying in 1944, he most likely committed suicide using cyanide pills when his hiding place was discovered, hence the manuscript cannot even be considered 'survivor testimony'. Indeed, Perechodnik depicts himself as a broken, almost lifeless, man from the beginning of his account, which he wrote while in hiding on the 'Aryan side'. Fully expecting to be captured and killed before the war's end, Perechodnik declares in a preface he wrote on 7 May 1943:

To be exact, this is a confession about my lifetime, a sincere and true confession. Alas, I don't believe in divine absolution, and as far as others are concerned, only my wife could - although she shouldn't - absolve me. However, she is no longer among the living. She was killed as a result of German brutality, and, to a considerable extent, on account of my recklessness. Please consider this my deathbed confession. [...] I don't ask to be absolved. ${ }^{34}$

While self-reproach for the violence done to his wife and others is perhaps understandable under the circumstances (yet to be revealed to the reader), it might be argued that such remorse is the result of the coercive actions of the Nazi German perpetrators and no cause for moral condemnation on Perechodnik's part. In fact, the reader is confronted with similar statements elsewhere in the manuscript, establishing an important framework through which to view the activities of the Jewish police.

In terms of Perechodnik's depiction of physical violence inflicted by 'privileged' Jews on other ghetto inhabitants, this is seldom described explicitly but can occasionally be read into his frequent and strong accusations against his colleagues. On the subject of rounding up the Jews for labour camps, Perechodnik notes that his own activities were restricted to distributing bread to wealthy, 'privileged' Jews: 'I didn't go out to seize people because I found it unbecoming, I was afraid of what people would say. In any case, I did not have the "sporting instinct" for that'. ${ }^{35}$ While survivor accounts are replete with incidents of beatings delivered by Jewish police and their truncheons, Perechodnik restricts himself to euphemistically suggesting that several ghetto functionaries enjoyed 'hunting' down Jews. Euphemisms regarding violence can generally be considered a strategy for obscuring its harm; thus Perechodnik's representational strategy distances himself (and his colleagues) from 
responsibility for violence. The ambiguous role of the Jewish police in deportations also appears in a long chapter entitled 'The Aktion', focusing on the Ordnungsdienst being forced to help the SS assemble 8,000 Jews for deportation to the Treblinka death camp.

On Wednesday 19 August, 1942, Perechodnik discovered that the Nazis planned to liquidate the Ghetto but had promised immunity for ghetto functionaries' families. When the police gathered their relatives outside the police station as instructed - Perechodnik had just brought his wife and daughter from their cellar hiding place - the Germans moved the crowd to the collection point to await the trains, still guaranteeing that the families would be separated out and freed. Perechodnik describes the chaos: 'policemen ran as if possessed, not knowing what they had to do - they blew whistles with all their strength and without pause. Everybody feared for himself and his family, ${ }^{36}$ The Nazis' promise was soon after exposed as false and the distraught police would shortly afterwards watch as their loved ones were taken to their certain deaths. First, however, the lie became a half-truth as wives and children were to be freed but not parents, whom their sons led to the trains. Of the twenty-seven page description devoted to events immediately leading up to and during the Ghetto's liquidation, Perechodnik describes this activity in uncharacteristic brevity:

\begin{abstract}
At last a group of policemen's wives is assembled on the side. They tell us to load the remaining people into cattle cars. $O$ cursed Germans! How wise are you! How quickly we become the obedient marionettes in your hands! We work briskly; the demon of revolt no longer dominates us, not even a feeling of pity for the remaining Jews. [...] The policemen lead their own fathers and mothers to the cattle cars; themselves close the door with a bolt - just as if they were nailing the coffins with their own hands. ${ }^{37}$
\end{abstract}

The betrayal is then completed as the German perpetrators themselves load the remaining Jews into the last wagon, while husbands, fathers, and brothers looked on helplessly; 'marionettes' evokes their lack of agency. Most of Perechodnik's reflections on this event centre on guilt at failing to save his family, and his meditations on what they must have thought about him for this. That the Jewish police had earlier been charged with loading the rest of the Ghetto's population into the wagons remains implicit, and his description of multiple executions by shooting makes it clear that the German and Ukrainian guards held the real power, and prescribed a completely different form of violence from the rounding up of Jews by the police.

Underlining Rozett's above-mentioned point regarding the principal value of Holocaust testimonies residing in their communication of the horror of victim experiences, Perechodnik's account of the Ghetto's liquidation fittingly ensures that the reader's attention is focused on the trauma experienced by the persecuted - the 'privileged' Jews who (temporarily) remained behind to clear the Ghetto as well as the deportees. Importantly, the manuscript makes clear the dehumanising effect of the ethical dilemmas facing 'privileged' Jews, with Perechodnik describing himself as 'without feeling about anything' after losing his family. ${ }^{38}$ Having felt deeply ashamed that he did not, as one colleague and friend did, remove his police cap and armband and board the train with his family, Perechodnik fluctuates between personal feelings of shame and broader condemnations of the Otwock Ordnungsdienst: 'For three years of occupation they sucked Jewish blood, collected constantly a bribe from [...] every Jew who traded or who had any goods hidden since before the war. ${ }^{39}$ The vampiric 
imagery here characterises non-physical exploitation as violent, but the use of 'they' attributes this only to his colleagues.

One significant problem raised by Perechodnik's acerbic criticism of those around him is his characterisation of other victims - not only 'privileged' colleagues in the Ordnungsdienst, but also Jewish leaders and 'non-privileged' Jews in the Ghetto - thus underlining the necessity of reading survivor testimony with a critical eye. Perechodnik's frequent negative judgements of other Jews contain contradictions, and almost as if projecting his shame onto other victims as a coping mechanism, he seems to find it easier to chastise the behaviour of Jews in other settings that he did not experience but had heard about. For example, while his discussion of the activities of Jewish police in the Warsaw Ghetto acknowledges that they were ordered to fill a daily 'arrest' quota during the several months of deportations to Treblinka, he condemns them rather than connect their desperate situation with the 'choiceless choice' he himself faced:

\begin{abstract}
Their hearts turned to stone; all human feelings became foreign to them. They grabbed people, they carried in their arms infants from the apartments, they robbed if there was an opportunity. So it was not surprising that Jews hated their own police more than they did the Germans, more than the Ukrainians. ${ }^{40}$
\end{abstract}

The more explicitly violent description of the Warsaw Ghetto police is significant, as it creates a strong contrast with Perechodnik's representation of himself and his colleagues during their Ghetto's liquidation, which is only violent through metaphor and euphemism. He is even less generous with some Jewish Council officials, who, he writes, 'died the deserved death of traitors of the Jewish people'. ${ }^{41}$ The Jewish community in general is lambasted on frequent occasions, at one point characterising a group of soon-to-be-deported Jews as 'huddled like lambs [...] so that the executioners would not have to work too hard'. ${ }^{42}$ Such judgements within the text place the reader in a difficult position, requiring them to keep in mind the impossible situation forced onto Perechodnik while also having an ethical obligation to doubt, question, and resist his inflammatory accusations against other Jews. The problem of judgement and the ambiguities of violence in relation to 'privileged' Jews can also be found in Holocaust testimony relating to the camps, as seen in Paul Steinberg's equally traumatised account of his time as a 'privileged' prisoner in Auschwitz.

\title{
'Can one be so guilty for having survived?': Paul Steinberg
}

Steinberg was an assimilated French Jew deported to Auschwitz when he was sixteen years old. Like Perechodnik's diary, his memoir was published some time after the war, though for different reasons. While Perechodnik's story was deemed too inflammatory and censored, Steinberg did not write about his experiences until some fifty years after the events due to his trauma; he had attempted to do so in the 1960s and could not continue. He notes in the early pages of his recollections: 'The one thing I am sure of is that writing this will knock me off balance, deprive me of a fragile equilibrium achieved with the utmost care'. ${ }^{43}$ On occasions like this, Steinberg's efforts at self-representation involve a form of rhetorical 'violence' on the self. Counter to the dominant discourse surrounding memory, the dredging up of the past is presented as not always cathartic and regenerative, a point that becomes increasingly evident in Steinberg's account. 
In representing the network of prisoners responsible for administration and discipline, he at times seems to show an awareness of the inherently judgemental role language plays, although his memoir is replete with judgements of various 'privileged' inmates that range span admiration, condemnation and ambivalence. Writing at length of Hugo, a German-Jewish Kapo, who had likely survived three or four years in Buna-Monowitz, rising to lead a squad of engineers and chemists, Steinberg writes:

\section{He doesn't overdo it. He's a Kapo you can live with. True, he's in charge of a Kommando of considerable value; perhaps in earlier days, with other groups, he laid on the stick with proper zeal. He doesn't treat us to the carrot, of course, but relations are rarely tense and sometimes almost human. ${ }^{44}$}

This highly significant passage makes it clear that behaviour under Nazi persecution conformed to some degree to the perceived necessities of prisoners' situations. Physical violence by prisoner-functionaries was encouraged less toward the end of the war, when forced labour was more difficult to locate which also increased the number of Jewish prisoners holding 'privileged' positions. Significantly, Levi himself notes that Jewish Kapos were arguably under more pressure to keep their positions through violence. ${ }^{45}$ In Steinberg's ambivalent portrayal of Hugo's violent potential, he emphasises the perverted and degrading atmosphere of the camp, while the exact meaning of 'he doesn't treat us with the carrot, of course' is left ambiguous.

Steinberg's representation of his own position(s) in the camp is also intricate, openly acknowledging the 'privileges' his situation afforded him and frequently shifting between dismay at his behaviour and self-justification of his need to survive however he could. While Steinberg claims that he never belonged to the 'Prominenz ['Prominents'], the camp aristocracy', a combination of veteran status in the camp (having survived for fifteen months) and 'powerful protectors' ensured he was considered 'an influential man'. ${ }^{46}$ While noting that he was 'helplessly kicked around by events', Steinberg concedes that had he been incarcerated in Auschwitz for a longer period of time, he 'would certainly have wound up a senior block inmate, at least'. ${ }^{47}$ However, immediately after this statement, he reiterates the importance of contextual factors on one's behaviour: 'I know from experience that every situation in camp is unstable, that someone soaring today can come crashing down tomorrow'. ${ }^{48}$ Steinberg routinely describes his efforts to ensure that newly arrived prisoners claimed to have what the Nazis deemed a 'useful' profession, such as metal worker or carpenter, so that they would not be 'selected' for immediate death in the gas chambers. ${ }^{49}$ However, he does not glamorise what are undeniably acts of resistance by employing a heroic discourse, but rather includes this brief description as part of a chapter entitled 'The Slap', which primarily focuses on his abuse of a fellow prisoner and inspired the title of this article.

After describing the 'material advantages and some self-satisfaction' he obtained from helping to keep order in his barracks by inspecting bunks, he recounts an incident of October 1944 when he ordered an elderly Polish Jew to get up and make his bed. When the man responded in Yiddish, Steinberg (who did not speak the language) claims to have taken this as a sign of defiant refusal and instinctively moved to strike the prisoner. The subsequent fragmentary passage, poignantly and significantly written in the present tense, is worth quoting in full: 
Furious, I raise my hand without thinking and slap him. At the last moment, I hold back and my hand just grazes his cheek. In that fraction of a second, I sound the abyss. despair.

I see his eyes. Eyes that speak of waiting, resignation, contempt,

Eyes brimming with exhaustion, with disgust at himself and his fellowman [sic]. Eyes watching the approach of death with a mixture of fear and longing.

Eyes without tears or reproaches. Just a blink in expectation of a slap from a hand. My hand.

And perhaps all this is sheer invention. Perhaps he was simply staring into space, like an animal in an abattoir, and perhaps that message in his eyes was my own imagination. My projection onto him of all the phantasms teeming inside me.

Perhaps it was merely the image of what I had been some eight months earlier. The approach of my own death, of which I had been aware at the time and which I hated at that precise moment. hand... ${ }^{50}$

If only I could get rid of this memory, sweep it away with my

This intriguing vignette highlights many of the issues we are concerned with here, making clear that the violence doubles back on the (oppressed) as well as the abuser's act of violence toward the abused.

Unlike Perechodnik's sweeping judgements of Jewish passivity, Steinberg hesitates to confidently depict - much less condemn - the 'passive' reaction of this Polish Jew. It is of crucial ethical importance that Steinberg even questions his ability to represent an/other, given the trauma experienced on both sides of the slap in the face. Indeed, he begins the following section of his memoir by further analysing the incident, stressing that 'I cannot say what his reaction was, whether he got up, whether he made his bed, or what happened to him'. 51 He details his unsuccessful attempt in the 1960s to write a novel called The Slap, which drew on this event; the project almost sent him mad and toward potential suicide. The narrative of Steinberg's (ongoing) trauma conflicts with his brief guilt-ridden judgement of his own behaviour as akin to that of killers in the Cambodian and Rwandan genocides. Carrying the memory of the Polish Jew - 'one of the abject wounds that can never heal' - with him since their brief encounter, his testimony again emphasises the role that the univers concentrationnaire ${ }^{52}$ had on victims. Reflecting a similar sentiment to that of Levi's essay on the 'grey zone', Steinberg writes shortly after his description of the slap: 'So the contagion had done its job, and I had not escaped corruption. In that world of violence, I'd made a gesture of violence, thus proving that I had taken my proper place there'. 53 Thus Steinberg holds in balance his own agency ('I'd made a gesture of violence') and the Nazi 'contagion' that is culpable for it. Held alongside his account a few chapters earlier of his 'sole glorious deed' in giving another elderly man his rations, ${ }^{54}$ the account of 'the slap' firmly places the reader in the complicated situation of having to navigate the impossible-toevaluate intent, volition, and consequences involved in Steinberg's experiences.

The intersection between Steinberg and Levi's writings is much more direct than their similar perspectives on the corrupting influence of Auschwitz. Indeed, the two prisoners were both held Buna-Monowitz - briefly even as part of the same work detail. Unbeknownst to Steinberg at the time, Levi wrote about him shortly after the war in his first memoir. Employing the name 'Henri' as an alias, Levi positions Steinberg as one of four exemplars of the Hobbesian camp environment in his testimony's central chapter, 'The Drowned and the Saved'. Somewhat different from his later call to suspend judgement in 'The Grey Zone', Levi's evaluation here is clear-cut in appropriating negative 
descriptors, militaristic connotations, and biblical metaphor, describing 'Henri' as 'intent on his hunt and his struggle; hard and distant, enclosed in armour, the enemy of all, inhumanly cunning and incomprehensible like the Serpent in Genesis' ${ }^{55}$ In what seems a definitive dismissal of Steinberg's efforts to survive, Levi ends his analysis of his 'case study' with, 'I know that Henri is living today. I would give much to know his life as a free man, but I do not want to see him again. ${ }^{56}$

Significantly, Steinberg's aptly titled memoir, Speak You Also (published almost half a decade after Levi's judgement) responds to the now-deceased survivor without anger or denial. Steinberg interrupts his mostly chronological narrative with short chapters ('Digressions') one of which is positioned directly after 'The Slap' and addresses Levi's representation. Steinberg notes that he was only eighteen when they were acquainted (four years younger than Levi had claimed). Yet fluctuating between self-justification and despair, Steinberg mournfully writes that Levi

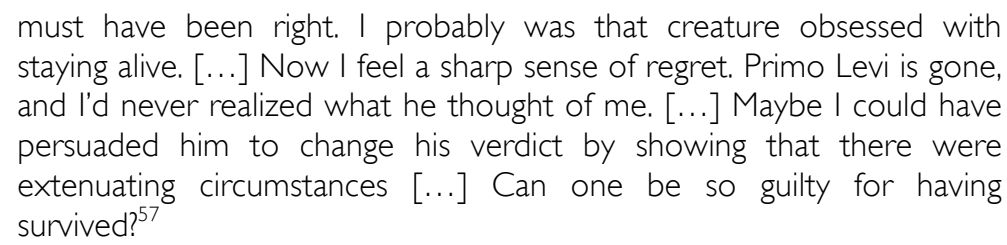

The precariousness of the act of passing judgement is particularly evident in the fact that Steinberg agrees with Levi's portrayal at times, calling him a 'neutral' and 'surely objective observer" ${ }^{58}$ - a characterisation that readers familiar to both testimonies might readily (and respectfully) disagree with. Steinberg writes as if Levi had presided over a full, criminal trial, resulting in a guilty 'verdict', which underscores the seriousness and finality of the judgement. Exemplifying the ethical dilemmas confronting 'privileged' Jews, Steinberg's detailed and traumatised narrative of his desperate efforts to stay alive through various 'privileged' means situates him firmly within the 'grey zone' of moral ambiguity that Levi wrote about some decades later.

\section{Conclusion}

Our analysis of the testimonies of former 'privileged' Jews reveals that Calel Perechodnik and Paul Steinberg employ representational strategies that (inevitably) pass judgement. Deeply traumatised and refusing to absolve himself of his 'complicity', Perechodnik nonetheless portrays his own violence, and that of his colleagues, through metaphor or euphemism, while making explicit judgements of Jewish police, council leaders, and other victims in other ghettos. By contrast, Steinberg directly attributes agency for violence to himself, while simultaneously highlighting the Nazi influence that 'corrupted' him. The periodic fluctuations between self-justification, self-loathing and despair in both testimonies highlight the ethical dilemmas that these victims faced. As Steinberg suggests, the camp and ghetto environments provided 'extenuating', although not exculpatory, circumstances, given the harm that (some of) their actions caused to fellow prisoners. The issue of how to understand - how to judge - these actions is a vexed one.

Exploring the devastating impact of the Holocaust on pre-existing moral frameworks, John K. Roth stresses the need to 'reconsider and retrieve ethics, to recover and renew its vitality in the ruins of a post-Holocaust world'. ${ }^{59}$ Holocaust testimony is clearly one crucial avenue through which to attempt 
this, and more research into the ambiguities of violence in (self-)representations of 'privileged' prisoners in the ghettos and camps is needed. An ethics of reading traumatised accounts of so-called 'moral compromise' by victims whose freedom of choice dissipated with the extremity of their unprecedented persecution is paramount, with acknowledgement of the interrelated problems of judgement and representation necessary to avoid overlooking the 'choiceless choices' confronted by these figures of the 'grey zone'. The 'privileged' positions that numerous victims held must always be considered in the context of the 'divide and conquer' practices of the Nazi perpetrators; and the extreme situations these engendered in the camps and ghettos. As a result of these settings, various forms of violence can be found in the experiences of Perechodnik and Steinberg, and their testimonies (along with Levi's) must be looked on with a critical eye - but also with pity and compassion. Doing so will only contribute to a deepening of understandings of the Holocaust: by attending to the traumas of both abused and abuser in the realm of 'privilege' and 'compromise', one might glimpse a reflection of the other side of a slap in the face.

\section{Deakin University and Monash University, Australia}

\section{Notes}

$1 \quad$ Jean Améry, At the Mind's Limits: Contemplations by a Survivor on Auschwitz and its Realities, trans. by Sidney Rosenfeld and Stella P Rosenfeld (New York: Schocken, 1986), p. 28 (author's emphasis). Calel Perechodnik, Am I a Murderer?: Testament of a Jewish Ghetto Policeman, trans. by Frank Fox (Boulder: Westview, 1996); Paul Steinberg, Speak You Also: A Survivor's Reckoning trans. by Linda Coverdale and Bill Ford, (New York: Henry Holt and Company, 2000). Primo Levi, If This Is a Man; and, The Truce, trans. by Stuart Woolf (London: Abacus, 1995).

Primo Levi, 'Foreword' to The Night of the Girondists, trans. by Barrows Mussey (London: Harvill, 1992), p. x.

Elie Wiesel, And the Sea Is Never Full: Memoirs, 1969-, trans. by Marion Wiesel (New York: Alfred A. Knopf, 1999), p. 347.

Primo Levi, The Drowned and the Saved, trans. by Raymond Rosenthal (London: Michael Joseph, 1988) p. 41.

For a detailed conceptualisation and justification of the category of 'privileged' Jews, see Adam Brown, Judging 'Privileged' Jews: Holocaust Ethics, Representation, and the 'Grey Zone'(New York: Berghahn, 2013), pp. 1-19.

Levi, The Drowned and the Saved, p. 22.

See Adam Brown, 'Confronting "Choiceless Choices" in Holocaust Videotestimonies: Judgement, "Privileged" Jews, and the Role of the Interviewer', Continuum: Journal of Media and Communication Studies - Special Issue: Interrogating Trauma: Arts \& Media Responses to Collective Suffering, 4.1 (2010), pp. 79-90; Adam Brown, 'Beyond "Good" and "Evil": Breaking Down Binary Oppositions in Holocaust Representations of "Privileged" Jews', History Compass, 8.5 (2010), pp. 407-18; Adam Brown, 'Narratives of Judgement: Representations of "Privileged" Jews in Holocaust Documentaries', LISA e-journal - Special Issue: Narrative practices and documentary film-making in the English-speaking world: From propaganda to dissent, 13.1 (2014) $<$ http://lisa.revues.org/5652 >.

Levi, The Drowned and the Saved, p. 50.

Levi, The Drowned and the Saved, p. 34.

Filip Müller, Auschwitz Inferno: The Testimony of a Sonderkommando (London: Routledge \& Kegan Paul, 1979), p. 131.

Améry, p. 90. 
Améry, p. 91.

15 Abraham Biderman, The World of My Past (1995; Sydney: Milsons Point, 1998), pp. 186-188; Jacob G. Rosenberg, East of Time (Blackheath: Brandl and Schlesinger,

2005), pp. 155-156

Lucille Eichengreen, Rumkowski and the Orphans of Lodz (San Francisco: Mercury House, 2000).

17 See, for example, Christopher Bigsby, Remembering and Imagining: The Chain of Memory (Cambridge: Cambridge University Press, 2006); Michael Bernard-Donals and Richard Glejzer, Between Witness and Testimony: The Holocaust and the Limits of Representation (Albany: State University of New York Press, 2001); Annette Wieviorka, The Era of the Witness, trans. by Jarod Stark (Ithaca \& London: Cornell University Press, 2006). Miklos Nyiszli, Auschwitz: A Doctor's Eyewitness Account, trans. by Tibere Kremer and Richard Seaver (New York: Arcade, 1993); Gisella Perl, I Was a Doctor in Auschwitz (Salem: Ayer, 1992); Adam Czerniakow, The Warsaw Diary of Adam Czerniakow: Prelude to Doom, ed. by Raul Hilberg, Stanislaw Staron, and Josef Kermisz (New York: Stein and Day, 1979). Lawrence L. Langer, Versions of Survival: The Holocaust and the Human Spirit (Albany: State University of New York Press, 1982), p. 72. Ella Lingens-Reiner, Prisoners of Fear (London: Victor Gollancz, 1948), p. 82. Giuseppi Grassano, 'A Conversation with Primo Levi (1979)', in The Voice of Memory: Interviews 1961-87, ed. by Marco Belpoliti and Robert Gordon (Cambridge: Polity, 2001), pp.121-135 (p. 132); Levi, If This Is a Man; and, The Truce, p. 73; Levi, The Drowned and the Saved, p. 55. Primo Levi, Moments of Reprieve, trans. by Ruth Feldman (London: Abacus, 1990), p. 30. Levi, Moments of Reprieve, p. 31. Quoted from 'Germaine Greer Talks to Primo Levi (1985)', in The Voice of Memory: Interviews 1961-87, ed. by Marco Belpoliti and Robert Gordon (Cambridge: Polity, 2001), pp. 3-12 (p. 6). Dominick LaCapra, Writing History, Writing Trauma (Baltimore: The Johns Hopkins University Press, 2001), p. 87. Robert Rozett, Approaching the Holocaust: Texts and Contexts (London: Vallentine Mitchell, 2005), pp. 100-101. John K. Roth, Ethics During and After the Holocaust: In the Shadow of Birkenau (Houndmills: Palgrave Macmillan, 2005), p. 60 (our emphasis). For a detailed discussion of the Jewish police, see Isaiah Trunk, Judenrat: The Jewish Councils in Eastern Europe under Nazi Occupation (New York: Scarborough, 1977), pp. 475-527. For another example of this rare testimony, see Stanislaw Adler, In the Warsaw Ghetto 1940-1943: An Account of a Witness (Jerusalem: Yad Vashem, 1982).

Zoë Waxman, Writing the Holocaust: Identity, Testimony, Representation (Oxford: Oxford University Press, 2006), p. 38.

Paweł Szapiro, 'Afterword', in Perechodnik, Am I a Murderer?, pp. 213-25 (p. 214). Frank Fox, 'Foreword', in Perechodnik, Am I a Murderer?, pp. ix-xix (p. xvi).

Perechodnik, p. 155.

Perechodnik, p. xxi.

Perechodnik, p. 14.

Perechodnik, p. 32.

Perechodnik, pp. 44-45.

Perechodnik, p. 110.

Perechodnik, p. 30.

Perechodnik, p. 104.

Perechodnik, p. 150.

Perechodnik, p. 29.

Steinberg, p. 15.

Steinberg, p. 110.

Levi, If This Is a Man; and, The Truce, pp. 96-97.

Steinberg, p. 121.

Steinberg, pp. 105, 121.

Steinberg, p. 122.

Steinberg, p. 123.

Steinberg, p. 126.

Steinberg, p. 126. 
52 This term is taken from the title of Rousset's highly influential work published in English as David Rousset, A World Apart, trans. by Yvonne Moyse and Roger Senhouse (London: Secker and Warburg, 1951).

Steinberg, p. 127.

Steinberg, p. 108

Levi, If This Is a Man; and, The Truce, p. 106.

Levi, If This Is a Man; and, The Truce, p. 106.

Steinberg, pp. 130-131.

Steinberg, p. 130.

Roth, p. xi.

\section{Works Cited}

Adler, Stanislaw, In the Warsaw Ghetto 1940-1943: An Account of a Witness (Jerusalem: Yad Vashem, 1982)

Améry, Jean, At the Mind's Limits: Contemplations by a Survivor on Auschwitz and Its Realities, trans. by Sidney Rosenfeld and Stella P Rosenfeld (New York: Schocken, 1986)

Bernard-Donals, Michael, and Glejzer, Richard, Between Witness and Testimony: The Holocaust and the Limits of Representation (Albany: State University of New York Press, 2001)

Biderman, Abraham, The World of My Past (Sydney: Milsons Point, 1998)

Bigsby, Christopher, Remembering and Imagining: The Chain of Memory, (Cambridge: Cambridge University Press, 2006)

Brown, Adam, "Beyond "Good" and "Evil": Breaking Down Binary Oppositions in Holocaust Representations of "Privileged" Jews', History Compass, 8.5 (2010), pp. 407-18

'Confronting "Choiceless Choices" in Holocaust Videotestimonies: Judgement, "Privileged" Jews, and the Role of the Interviewer', Continuum: Journal of Media and Communication Studies - Special Issue: Interrogating Trauma: Arts \& Media Responses to Collective Suffering, 4.1 (2010), pp. 79-90

_ Judging 'Privileged' Jews: Holocaust Ethics, Representation, and the 'Grey Zone'(New York: Berghahn, 2013)

'Narratives of Judgement: Representations of "Privileged" Jews in Holocaust Documentaries', LISA e-journal - Special Issue: Narrative practices and documentary film-making in the English-speaking world: From propaganda to dissent, 13.1 (2014) < http://lisa.revues.org/5652>

Czerniakow, Adam, The Warsaw Diary of Adam Czerniakow: Prelude to Doom, ed. by Raul Hilberg, Stanislaw Staron, and Josef Kermisz (New York: Stein and Day, 1979)

Eichengreen, Lucille, Rumkowski and the Orphans of Lodz (San Francisco: Mercury House, 2000)

Grassano, Giuseppi, 'A Conversation with Primo Levi (1979)', in The Voice of Memory: Interviews 1961-87, ed. by Marco Belpoliti and Robert Gordon (Cambridge: Polity, 2001), pp. 121-35

Greer, Germaine, 'Germaine Greer Talks to Primo Levi (1985),' in The Voice of Memory: Interviews 1961-87, ed. by Marco Belpoliti and Robert Gordon (Cambridge: Polity, 2001), pp. 3-12

LaCapra, Dominick, Writing History, Writing Trauma (Baltimore: The Johns Hopkins University Press, 2001) 
Langer, Lawrence L., Versions of Survival: The Holocaust and the Human Spirit (Albany: State University of New York Press, 1982)

Levi, Primo, If This Is a Man; and, The Truce, trans. by Stuart Woolf (London: Abacus, 1995)

The Drowned and the Saved, trans. by Raymond Rosenthal (London: Michael Joseph, 1988)

Moments of Reprieve, trans. by Ruth Feldman (London: Abacus, 1990)

Lingens-Reiner, Ella, Prisoners of Fear (London: Victor Gollancz, 1948)

Müller, Filip, Auschwitz Inferno: The Testimony of a Sonderkommando (London: Routledge \& Kegan Paul, 1979)

Nyiszli, Miklos, Auschwitz: A Doctor's Eyewitness Account, trans. by Tibere Kremer and Richard Seaver (New York: Arcade, 1993)

Perechodnik, Calel, Am I a Murderer?: Testament of a Jewish Ghetto Policeman, trans. by Frank Fox (Boulder: Westview, 1996)

Perl, Gisella, I Was a Doctor in Auschwitz (Salem: Ayer, 1992)

Presser, Jacques, The Night of the Girondists, trans. by Barrows Mussey (London: Harvill, 1992)

Rosenberg, Jacob G., East of Time (Blackheath: Brandl \& Schlesinger, 2005)

Rousset, David, A World Apart, trans. by Yvonne Moyse and Roger Senhouse (London: Secker and Warburg, 1951)

Roth, John K., Ethics During and After the Holocaust: In the Shadow of Birkenau (Houndmills: Palgrave Macmillan, 2005)

Rozett, Robert, Approaching the Holocaust: Texts and Contexts (London: Vallentine Mitchell, 2005)

Steinberg, Paul, Speak You Also: A Survivor's Reckoning trans. by Linda Coverdale and Bill Ford (New York: Henry Holt and Company, 2000)

Trunk, Isaiah, Judenrat: The Jewish Councils in Eastern Europe under Nazi Occupation (New York: Scarborough, 1977)

Waxman, Zoë, Writing the Holocaust: Identity, Testimony, Representation (Oxford: Oxford University Press, 2006)

Wiesel, Elie, And the Sea Is Never Full: Memoirs, 1969-, trans. by Marion Wiesel (New York: Alfred A. Knopf, 1999)

Wieviorka, Annette, The Era of the Witness, trans. by Jarod Stark (Ithaca \& London: Cornell University Press, 2006) 